\title{
Development and optimization of a sublingual tablet formulation for physostigmine salicylate
}

\author{
NOUSHIN BOLOURCHIAN ${ }^{* 1,2}$ \\ NAGHMEH HADIDI ${ }^{1}$ \\ SEYED MOHSEN FOROUTAN ${ }^{1,2}$ \\ BIJAN SHAFAGHI ${ }^{1,2}$ \\ ${ }^{1}$ School of Pharmacy, Shahid Beheshti \\ University of Medical Sciences \\ Tehran, Iran \\ ${ }^{2}$ Pharmaceutical Sciences Research Center \\ Shahid Beheshti University of Medical \\ Sciences, Tehran, Iran
}

Accepted July 13, 2009

\begin{abstract}
This study is aimed to design and optimize a sublingual tablet formulation of physostigmine salicylate, an effective drug in Alzheimer's disease and nerve gas poisoning, by means of the D-optimal experimental design methodology. Polyvinyl pyrrolidone, lactose, starch 1500 and sodium starch glycolate were used in the formulations as independent variables. Tablets were prepared by the direct compression method and evaluated for their physical properties (tablet hardness, disintegration time and friability), which were regarded as responses in a D-optimal design. Due to the significance of the special cubic model for data fitted, compared to other models, it was used to examine the obtained results. Response surface plots were plotted to study the tablet properties and the optimized overlay plot was generated based on the results and targets considered for the responses. After verification of the optimum checkpoint formulations, an optimized formulation was chosen due to its desirable physical properties and closely observed and predicted values. Drug assay, content uniformity of the dosage unit, drug dissolution and accelerated stability studies were done on the optimum formulation as further experiments. All the obtained results complied with the requirements of a sublingual tablet formulation.
\end{abstract}

Keywords: D-optimal mixture design, physostigmine salicylate, sublingual tablet, stability studies

Physostigmine salicylate, a reversible inhibitor of cholinesterase activity (1) may be an effective drug in the management of Alzheimer's disease $(2,3)$ and may be also used in the treatment of nerve gas poisoning (2). It is readily absorbed from the gastrointestinal tract (1) and undergoes extensive presystemic metabolism (2), which results in poor bioavailability of its oral dosage forms $(2,3)$. Short elimination half-life of this drug (3) makes repeated injections at short time intervals necessary and causes poor patient compliance. Therefore preparation of a suitable and more effective dosage form of this drug is needed.

\footnotetext{
* Correspondence; e-mail: nbolourtchian@yahoo.com
} 
Sublingual administration is an alternative route with better patient compliance, which avoids the first pass effect and gives acceptable bioavailability (4). For this reason, formulation of a physostigmine salicylate sublingual tablet could be a proper method for obtaining the desired results for this drug.

Experimental design is an approach in the development and optimization of drug delivery devices. This method enables the desired formulation to be achieved as fast as possible (5-7). Process validation and scale-up can also be very efficient due to the robustness of the formulation and manufacturing process (7). Mixture plan is a widely practiced approach to design pharmaceutical formulations with appropriate properties. In a mixture experiment, the factors are the components of a mixture and the response is the function of the proportions of each ingredient (8). D-optimal designs can be customized to fulfill classical mixture designs. These designs are more robust to constraints and can produce complex designs with many design constraints.

D-optimal design has been used in optimization of various drug delivery devices (9-12). The present study deals with the optimization of formulation variables using mathematical equations and response surface plots, in order to prepare the desired sublingual tablet of physostigmine salicylate with suitable physical and chemical characteristics. Due to the limitations considered for physical properties of sublingual tablets such as hardness and disintegration time, the D-optimal design can be a very useful approach to rapidly achieve the optimum formulation that could be efficiently scaled-up.

\section{EXPERIMENTAL}

\section{Materials}

The active ingredient, physostigmine salicylate, was purchased from Sigma (UK). The other materials were as follows: polyvinyl pyrrolidone (PVP K10) and ammonium acetate (Sigma), starch 1500 (Colorcon, UK), sodium starch glycolate (Agrokemia Sellye, Hungary), lactose, talc, magnesium stearate and acetonitrile HPLC grade (Merck, Germany).

\section{Experimental design}

D-optimal mixture design was used to evaluate the effect of changes in mixture compositions on dependent variables and statistical optimization of the formulation with the least number of experiments (8). D-optimal designs are straight optimizations based on a chosen optimality criterion and the model that will be fitted. Both process and mixture optimizations are possible by this method.

In a mixture design, the level of a single component cannot be changed independently (13) and the sum of the mixture components has to be equal to $100 \%$ (5). In the present case, tablets were prepared with a constant drug content $(4 \%)$, magnesium stearate $(1 \%)$ and talc $(0.2 \%)$. Therefore, the experimental range lay between 0 and $94.8 \%$ $(\mathrm{m} / \mathrm{m})$. Table I shows the restrictions imposed on the mixture component proportions. Constraints were applied based on the applicable amounts of the components in pharmaceutical formulations (14). Tablet hardness, disintegration time and friability were con- 
N. Bolourchian et al:: Development and optimization of a sublingual tablet formulation for physostigmine salicylate, Acta Pharm. 59 (2009) 301-312.

Table I. Experimental ranges for independent variables and constraints

\begin{tabular}{lccc}
\hline \multirow{2}{*}{ Factor } & \multicolumn{2}{c}{ Experimental range } & Constraint \\
\cline { 2 - 3 } & Low value (\%) & High value (\%) & \\
\hline$X_{1}(\mathrm{PVP})$ & 4.5 & 9.0 & $X_{1}+X_{2}+X_{3}+X_{4}=94.8$ \\
$X_{2}$ (starch 1500) & 9.5 & 14.0 & $X_{1}+X_{2}+X_{3}+X_{4}=94.8$ \\
$X_{3}$ (lactose) & 64.0 & 74.0 & $X_{1}+X_{2}+X_{3}+X_{4}=94.8$ \\
$X_{4}$ (sodium starch glycolate) & 1.5 & 8.0 & $X_{1}+X_{2}+X_{3}+X_{4}=94.8$ \\
\hline
\end{tabular}

Table II. Dependent variables and the constraints applied to responses

\begin{tabular}{ll}
\hline Response & Constraint \\
\hline$Y_{1}$ (hardness) & $21-28 \mathrm{~N}$ \\
$Y_{2}$ (disintegration time) & $20-60 \mathrm{~s}$ \\
$Y_{3}$ (friability) & $0.01-0.7 \%$ \\
\hline
\end{tabular}

sidered as dependent variables (responses) in this study. Table II shows these variables and their acceptable ranges for a sublingual tablet.

Design-Expert software (version 7, Stat-Ease Inc., USA) was used for experimental design and statistical evaluation of the data.

\section{Tablet preparation}

Accurate amount of the active ingredient and all additives were homogeneously blended using geometric dilution after passing through a $500-\mu \mathrm{m}$ screen sieve. Magnesium stearate and talc were then added to the mixture. Tablets were directly compressed by a single punch tableting machine (Erweka AR 4100, Erweka, Germany) equipped with a 5-mm flat-faced punch and die set. The compression force and mass of all tablets were kept constant and each tablet contained $4 \%$ of physostigmine salicylate.

\section{Tablet drug content}

Twenty drug containing tablets were powdered and extracted with acetonitrile and assayed for drug content by HPLC (Merck Hitachi, Germany) (15). Chromatography was performed at room temperature using the $4 \times 250 \mathrm{~mm}$ Lichrocart C18 column and the mobile phase consisting of acetonitrile-ammonium acetate $0.05 \mathrm{~mol} \mathrm{~L}^{-1}(1: 1)$ at a flow rate of $2 \mathrm{~mL} \mathrm{~min}^{-1}$. The drug was detected by a UV detector at $254 \mathrm{~nm}$. This test was carried out in triplicate for the optimized formulation. For content uniformity test, 10 tablets were powdered and extracted separately and the amount of drug in three random samples was determined. 


\section{Physical properties of tablets}

Tablet hardness (Erweka TBH 28) and friability (Erweka TA 63974) were checked following the standard methods. Disintegration test was carried out using a disintegration test apparatus (Erweka ZT6-1-D) at $37 \pm 0.5{ }^{\circ} \mathrm{C}$ in distilled water.

\section{Dissolution studies}

Optimized formulation was studied for drug dissolution in triplicate, employing a USP apparatus type II (paddle method, Erweka DT 6R) (15) at a rotating speed of 50 $\mathrm{rpm}$. The dissolution medium consisted of a phosphate buffer solution $\mathrm{pH} 6.8(500 \mathrm{~mL})$ at $37 \pm 0.5^{\circ} \mathrm{C}(16)$. Samples $(5 \mathrm{~mL})$ were withdrawn at predetermined time intervals and the volume was replaced with an equivalent amount of plain medium. The amount of drug dissolved in the dissolution medium was determined by the HPLC method described above for drug content.

\section{Stability studies}

Optimized formulation tablets were packed in suitable primary packaging and then kept at $45^{\circ} \mathrm{C}$ and $75 \%$ relative humidity $(\mathrm{RH})$ for 3 months in order to perform the accelerated stability test. At the end of each month, tablet properties including hardness, friability and disintegration time as well as drug content and dissolution were evaluated.

\section{RESULTS AND DISCUSSION}

\section{Analyzing of mixture data}

The concentration range of ingredients used to prepare the 20 formulations (runs) and the respective observed responses are given in Table III.

Preliminary statistical analysis (analysis of variance, ANOVA) of the experiments suggested that a non linear response function must be expected.

Different models could be used for interpreting the results of the D-optimal design (linear, quadratic, cubic and special cubic). Based on statistical significance of data fitting to these models $(p<0.05)$ and also insignificance of lack of fit, special cubic model was chosen for interpreting the results. The chosen model was fitted to the data for response $Y_{1}$ (hardness) $(p<0.05)$, but, according to the Box-Cox plot and for more precise analysis of the response data of friability $\left(Y_{3}\right)$, a transformation was needed and $\log Y_{3}$ was used. On the other hand, ANOVA analysis of the disintegration time data $\left(Y_{2}\right)$ indicated that the reduced form of the special cubic model can be used in a stepwise manner to obtain a simpler model.

The mathematical models generated for responses $Y_{1}, Y_{2}$ and $Y_{3}$ are as follows: 
N. Bolourchian et al:: Development and optimization of a sublingual tablet formulation for physostigmine salicylate, Acta Pharm. 59 (2009) 301-312.

$$
\begin{gathered}
Y_{1}=691.6 X_{1}+639.11 X_{2}+36.33 X_{3}+224.54 X_{4}-3420.59 X_{1} X_{2}-763.05 X_{1} X_{3} \\
-1066.47 X_{1} X_{4}-915.92 X_{2} X_{3}-1754.69 X_{2} X_{4}-361.75 X_{3} X_{4}+3482.52 X_{1} X_{2} X_{3} \\
+5175.47 X_{1} X_{2} X_{4}-853.81 X_{1} X_{3} X_{4}+2028.07 X_{2} X_{3} X_{4} \\
Y_{2}=-382.20 X_{1}-117.95 X_{2}+22.30 X_{3}+43.33 X_{4}+1491.33 X_{1} X_{2}+514.35 X_{1} X_{3} \\
+846.15 X_{1} X_{4}+213.01 X_{2} X_{3}+217.12 X_{2} X_{4}-1212.69 X_{1} X_{2} X_{3}-2758.22 X_{1} X_{2} X_{4} \\
\log Y_{3}=4.46 X_{1}+25.54 X_{2}-0.16 X_{3}+5.41 X_{4}-96.18 X_{1} X_{2}-15.81 X_{1} X_{3} \\
-33.56 X_{1} X_{4}-44.04 X_{2} X_{3}-37.99 X_{2} X_{4}-14.97 X_{3} X_{4}+145.55 X_{1} X_{2} X_{3} \\
+113.52 X_{1} X_{2} X_{4}+68.60 X_{1} X_{3} X_{4}-21.98 X_{2} X_{3} X_{4}
\end{gathered}
$$

Table III. Experimental plan for the D-optimal design and the results

\begin{tabular}{rrrrcccc}
\hline \multicolumn{7}{c}{ Variable factor $(\%)$} & \multicolumn{3}{c}{ Response } \\
\cline { 2 - 7 } Run & $\begin{array}{r}\text { PVP } \\
\left(X_{1}\right)\end{array}$ & $\begin{array}{c}\text { Starch } \\
1500\left(X_{2}\right)\end{array}$ & $\begin{array}{c}\text { Lactose } \\
\left(X_{3}\right)\end{array}$ & $\begin{array}{c}\text { Sodium starch } \\
\text { glycolate }\left(X_{4}\right)\end{array}$ & $\begin{array}{c}\text { Hardness } \\
(\mathrm{N})\left(Y_{1}\right)\end{array}$ & $\begin{array}{c}\text { Disintegration } \\
\text { time }(\mathrm{s})\left(Y_{2}\right)\end{array}$ & $\begin{array}{c}\text { Friability }(\%) \\
\left(Y_{3}\right)\end{array}$ \\
\hline 1 & 6.79 & 13.57 & 69.71 & 4.73 & 35.80 & 36.30 & 0.050 \\
2 & 4.75 & 9.50 & 75.81 & 4.74 & 15.76 & 20.00 & 0.033 \\
3 & 8.82 & 11.53 & 69.71 & 4.73 & 40.28 & 27.00 & 0.016 \\
4 & 4.75 & 9.50 & 72.97 & 7.58 & 26.27 & 24.60 & 0.033 \\
5 & 4.75 & 13.57 & 74.58 & 1.89 & 36.91 & 25.00 & 0.016 \\
6 & 6.79 & 13.57 & 69.71 & 4.73 & 33.76 & 33.00 & 0.067 \\
7 & 4.75 & 13.57 & 68.90 & 7.58 & 26.62 & 34.30 & 0.050 \\
8 & 7.60 & 11.33 & 72.84 & 3.03 & 29.28 & 37.75 & 0.016 \\
9 & 8.82 & 13.57 & 70.52 & 1.89 & 34.81 & 33.20 & 0.016 \\
10 & 4.75 & 13.57 & 68.90 & 7.58 & 29.21 & 35.00 & 0.047 \\
11 & 4.75 & 13.57 & 74.58 & 1.89 & 22.91 & 25.00 & 0.020 \\
12 & 8.82 & 13.57 & 64.83 & 7.58 & 31.31 & 27.70 & 0.016 \\
13 & 8.82 & 9.50 & 71.74 & 4.73 & 28.16 & 35.00 & 0.033 \\
14 & 8.82 & 13.57 & 67.67 & 4.73 & 30.54 & 36.50 & 0.016 \\
15 & 6.79 & 11.53 & 68.90 & 7.58 & 26.55 & 44.50 & 0.033 \\
16 & 8.82 & 13.57 & 64.83 & 7.58 & 30.05 & 32.30 & 0.010 \\
17 & 8.82 & 13.57 & 70.52 & 1.89 & 27.39 & 36.70 & 0.033 \\
18 & 6.79 & 9.50 & 76.62 & 1.89 & 36.92 & 25.00 & 0.033 \\
19 & 8.82 & 9.50 & 68.90 & 7.58 & 37.41 & 59.60 & 0.050 \\
20 & 4.75 & 9.50 & 78.65 & 1.90 & 36.43 & 26.00 & 0.700 \\
\hline
\end{tabular}


In the present study, PVP $\left(X_{1}\right)$, starch $1500\left(X_{2}\right)$, lactose $\left(X_{3}\right)$ and sodium starch glycolate $\left(X_{4}\right)$ had significant effects on physical properties of physostigmine sublingual tablets. Figures 1a-c show the response surface plots predicted from the special cubic model for hardness and friability and the reduced special cubic model for disintegration time. In these graphs, the response is shown as the function of PVP, starch 1500 and lactose, having fixed sodium starch glycolate to a value of $5.7 \%$ with respect to the total of 94.8 $\%$. These plots are very useful to illustrate the interaction effects of the factors on the responses. Referring to the ANOVA table (Table IV) $X_{1} X_{2}, X_{1} X_{3}, X_{1} X_{4}, X_{2} X_{3}, X_{2} X_{4}, X_{3} X_{4}$, $X_{1} X_{2} X_{3}, X_{1} X_{2} X_{4}$ and $X_{2} X_{3} X_{4}$ were significant model terms in the case of hardness $(p<$ 0.05). Based on Fig. 1a, it can be seen that increasing the percentage of PVP or starch

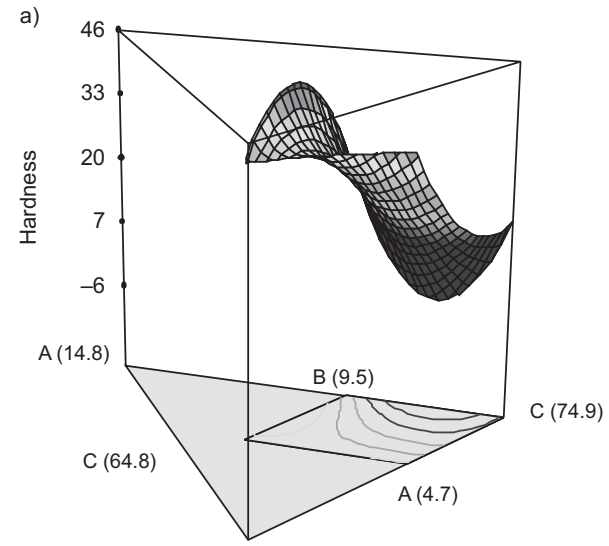

B (19.5)

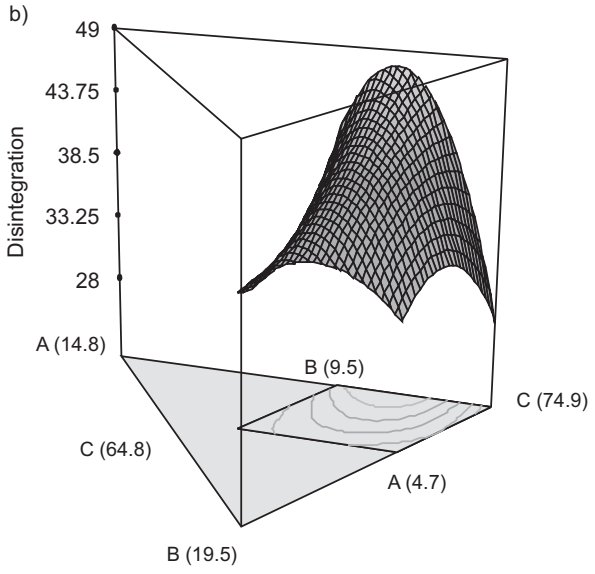

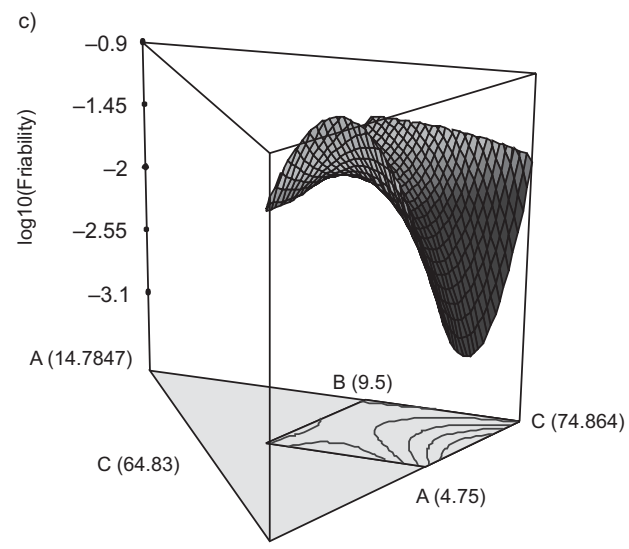

B (19.5347)

Fig. 1. 3D response surface plots for: a) hardness, b) disintegration time, c) log friability. Responses are shown as the function of A) PVP, B) starch 1500 and C) lactose, having fixed sodium starch glycolate to a value of $5.7 \%$. 
N. Bolourchian et al.: Development and optimization of a sublingual tablet formulation for physostigmine salicylate, Acta Pharm. $\mathbf{5 9}$ (2009) 301-312.

Table IV. Analysis of variance (ANOVA) of dependent variables

\begin{tabular}{|c|c|c|c|c|c|}
\hline Source of variation & $\begin{array}{l}\text { Sum of } \\
\text { squares }\end{array}$ & Degree of freedom & Mean square & $F$-ratio & $p$-value \\
\hline \multicolumn{6}{|l|}{$Y_{1}$ (Hardness) } \\
\hline$X_{1} X_{2}^{a}$ & 188.93 & 1 & 188.93 & 8.23 & 0.0083 \\
\hline$X_{1} X_{3}$ & 157.34 & 1 & 157.34 & 9.37 & 0.0111 \\
\hline$X_{1} X_{4}$ & 114.19 & 1 & 114.19 & 32.32 & 0.0013 \\
\hline$X_{2} X_{3}$ & 176.06 & 1 & 176.06 & 26.91 & 0.0020 \\
\hline$X_{2} X_{4}$ & 252.44 & 1 & 252.44 & 19.53 & 0.0045 \\
\hline$X_{3} X_{4}$ & 178.78 & 1 & 178.78 & 30.12 & 0.0015 \\
\hline$X_{1} X_{2} X_{3}$ & 140.69 & 1 & 140.69 & 43.19 & 0.0006 \\
\hline$X_{1} X_{2} X_{4}$ & 197.64 & 1 & 197.64 & 30.58 & 0.0015 \\
\hline$X_{1} X_{3} X_{4}$ & 30.39 & 1 & 30.39 & 24.07 & 0.0027 \\
\hline$X_{2} X_{3} X_{4}$ & 143.48 & 1 & 143.48 & 33.81 & 0.0011 \\
\hline Residuals & 35.07 & 6 & 5.84 & & \\
\hline Lack of fit (adj. $R^{2}=0.947^{\mathrm{b}}$ ) & 0.74 & 1 & 0.74 & 0.11 & 0.7553 \\
\hline \multicolumn{6}{|l|}{$Y_{2}$ (Disintegration time) } \\
\hline$X_{1} X_{2}$ & 82.99 & 1 & 82.99 & 4.50 & 0.0630 \\
\hline$X_{1} X_{3}$ & 139.27 & 1 & 139.27 & 7.54 & 0.0260 \\
\hline$X_{1} X_{4}$ & 246.21 & 1 & 246.21 & 13.34 & 0.0053 \\
\hline$X_{2} X_{3}$ & 17.24 & 1 & 17.24 & 0.93 & 0.3591 \\
\hline$X_{2} X_{4}$ & 16.63 & 1 & 16.63 & 0.90 & 0.3673 \\
\hline$X_{1} X_{2} X_{3}$ & 39.83 & 1 & 39.83 & 2.16 & 0.1760 \\
\hline$X_{1} X_{2} X_{4}$ & 152.60 & 1 & 152.26 & 8.25 & 0.0184 \\
\hline Residuals & 25.15 & 9 & 3.40 & & \\
\hline Lack of fit (adj. $R^{2}=0.890^{\mathrm{b}}$ ) & 143.77 & 4 & 35.94 & 8.02 & 0.2110 \\
\hline \multicolumn{6}{|l|}{$Y_{3}$ (Friability) } \\
\hline$X_{1} X_{2}$ & 0.15 & 1 & 0.15 & 10.13 & 0.0190 \\
\hline$X_{1} X_{3}$ & 0.07 & 1 & 0.07 & 4.58 & 0.0761 \\
\hline$X_{1} X_{4}$ & 0.11 & 1 & 0.11 & 7.67 & 0.0324 \\
\hline$X_{2} X_{3}$ & 0.41 & 1 & 0.41 & 27.61 & 0.0019 \\
\hline$X_{2} X_{4}$ & 0.12 & 1 & 0.12 & 8.03 & 0.0298 \\
\hline$X_{3} X_{4}$ & 0.31 & 1 & 0.31 & 20.76 & 0.0039 \\
\hline$X_{1} X_{2} X_{3}$ & 0.25 & 1 & 0.25 & 16.67 & 0.0065 \\
\hline$X_{1} X_{2} X_{4}$ & 0.10 & 1 & 0.10 & 6.45 & 0.0441 \\
\hline$X_{1} X_{3} X_{4}$ & 0.20 & 1 & 0.20 & 13.30 & 0.0107 \\
\hline$X_{2} X_{3} X_{4}$ & 0.02 & 1 & 0.02 & 1.14 & 0.3277 \\
\hline Residuals & 0.09 & 6 & 0.015 & & \\
\hline Lack of fit (adj. $\left.R^{2}=0.969^{\mathrm{b}}\right)$ & $5.07 \mathrm{E}-0.003$ & 1 & 5.07E-0.003 & 0.30 & 0.6051 \\
\hline
\end{tabular}


1500 and decreasing the amount of lactose in tablet formulation may result in a higher hardness value. This was predictable, because both PVP and starch 1500 have a binding effect in tablet formulation. For instance, an increase in starch 1500 concentration in tablets from 10 to $12 \%$, with the same amount of PVP, modified tablet hardness from 7.7 to 27.3 N. For the response of disintegration time $X_{1} X_{3}, X_{1} X_{4}$ and $X_{1} X_{2} X_{4}$ were significant model terms in the $Y_{2}$ equation. An area with the highest disintegration time can be observed in the response surface plot (Fig. 1b). Starch 1500 has a disintegrating effect and decreasing its percentage in tablet formulation might result in higher tablet disintegration time. It is obvious that with a fixed amount of sodium starch glycolate, incorporation of suitable amounts of starch 1500, lactose and PVP might lead to a desired disintegration time. $X_{1} X_{2}, X_{1} X_{4}, X_{2} X_{3}, X_{2} X_{4}, X_{3} X_{4}, X_{1} X_{2} X_{3}, X_{1} X_{2} X_{4}, X_{1} X_{3} X_{4}$ were significant $(p$ $<0.05)$ model terms for friability. Fig. 1c shows a saddle shape response surface plot for this dependent variable. It was estimated that increasing the binder concentration in tablet formulation could result in lower friability, but the resultant data showed that in a D-optimal mixture design the simultaneous effect of all components and interactions between the independent variables on the responses must be considered, which is an advantage of this plan.

\section{Optimization results}

The aim of optimization is to achieve the defined targets for all three responses simultaneously with respect to the predefined constraints. Suitable balancing between the levels of components is essential to acquire optimal tablet physical properties. For graphical optimization, the three plots for the responses were combined to determine an overall optimum region. The overlay plot provided by the Design-Expert software showed an acceptable region that met the requirement of these responses (Fig. 2).

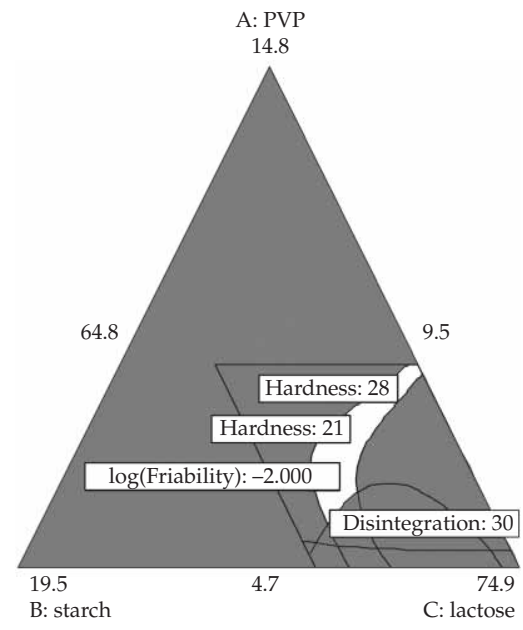

Fig. 2. The overlay plot showing the desired area of all three responses containing optimum formulations in white: A) PVP, B) starch 1500 and C) lactose, having fixed sodium starch glycolate to a value of $5.7 \%$. 
In numerical optimization, optimal formulations were found by multiple criteria optimization using desirable indices and the Derringer Suich method (17). Seven optimum checkpoint formulations $\left(\mathrm{O}_{1}-\mathrm{O}_{7}\right)$ with higher desirability $(100 \%)$ were selected in this step (Table $\mathrm{V})$. All the proposed optimized formulations were prepared and analyzed for the responses. Comparative values of predicted and observed responses are also reported in Table V.

Most of the formulations showed acceptance values for tablet physical properties. According to the literature, the hardness of sublingual tablets is sufficient to be in the range of 21-28 $\mathrm{N}$ (equal to 3-4 Strong Cobb) (18). The hardness of formulations $\mathrm{O}_{2}$ and $\mathrm{O}_{4}$ was, to some extent, above the constraint defined for this variable. For this reason, they were not regarded as optimum formulations. Among other formulations $\left(\mathrm{O}_{1}, \mathrm{O}_{3}\right.$ and $\mathrm{O}_{5}-\mathrm{O}_{7}$ ), the highest correlation (lowest difference) between the predicted (Pred) and observed (Obs) values for all three responses was detected for $\mathrm{O}_{1}$. This was confirmed by calculating the Euclidean distance (Ed) using the following equation (19):

$$
\mathrm{Ed}=\left(\Sigma_{i}\left(\operatorname{Pred}_{i}-\mathrm{Obs}_{i}\right)^{2}\right)^{1 / 2}
$$

$\operatorname{Pred}_{i}$ and $\mathrm{Obs}_{i}$ are predicted and observed values, respectively, of response $i$ and the summation was over all responses.

The Euclidean distance calculated for $\mathrm{O}_{1}$ was equal to 2.92. In addition, the friability of tablets prepared by this formulation was the lowest compared to other tablets. Therefore, $\mathrm{O}_{1}$ was selected as the optimum formulation for further studies.

\section{Drug content and dissolution studies}

Drug content study was conducted on tablets prepared using formulation $\mathrm{O}_{1}$. HPLC analysis confirmed $97.5 \pm 1.5 \%$ of active ingredient in tablets, which was within the

Table V. Validation step: optimized levels for independent variables and comparative values of predicted and observed responses for numerically optimized formulations

\begin{tabular}{|c|c|c|c|c|c|c|c|c|c|c|}
\hline \multirow{3}{*}{$\begin{array}{l}\text { Formu- } \\
\text { lation }\end{array}$} & \multicolumn{4}{|c|}{ Variable factor ${ }^{a}$} & \multicolumn{6}{|c|}{ Response } \\
\hline & \multirow[t]{2}{*}{$X_{1}$} & \multirow[t]{2}{*}{$X_{2}$} & \multirow[t]{2}{*}{$X_{3}$} & \multirow[t]{2}{*}{$X_{4}$} & \multicolumn{2}{|c|}{$\begin{array}{c}\text { Hardness }(\mathrm{N}) \\
(n=10)\left(Y_{1}\right)\end{array}$} & \multicolumn{2}{|c|}{$\begin{array}{l}\text { Disintegration time } \\
\quad(\mathrm{s})(n=6)\left(Y_{2}\right)\end{array}$} & \multicolumn{2}{|c|}{$\begin{array}{c}\text { Friability }(\%) \\
(n=20)\left(Y_{3}\right)\end{array}$} \\
\hline & & & & & Pred $^{b}$ & $\mathrm{Obs}^{\mathrm{c}, \mathrm{d}}$ & Pred $^{b}$ & $\mathrm{Obs}^{\mathrm{c}, \mathrm{d}}$ & Pred $^{b}$ & $\mathrm{Obs}^{\mathrm{c}}$ \\
\hline $\mathrm{O}_{1}$ & 8.38 & 10.16 & 71.70 & 4.56 & 26.55 & $24.93 \pm 1.30$ & 35 & $32.57 \pm 3.25$ & 0.005 & 0.002 \\
\hline $\mathrm{O}_{2}$ & 7.95 & 10.52 & 71.98 & 4.35 & 23.33 & $29.21 \pm 1.09$ & 35 & $33.80 \pm 0.46$ & 0.030 & 0.033 \\
\hline $\mathrm{O}_{3}$ & 6.06 & 12.68 & 70.49 & 5.57 & 26.27 & $21.40 \pm 0.71$ & 35 & $32.00 \pm 3.15$ & 0.011 & 0.016 \\
\hline $\mathrm{O}_{4}$ & 7.68 & 11.56 & 71.09 & 4.47 & 26.27 & $28.51 \pm 1.47$ & 35 & $28.00 \pm 0.75$ & 0.036 & 0.033 \\
\hline $\mathrm{O}_{5}$ & 5.19 & 11.96 & 70.81 & 6.84 & 22.28 & $24.03 \pm 0.97$ & 35 & $25.00 \pm 3.65$ & 0.029 & 0.033 \\
\hline $\mathrm{O}_{6}$ & 7.14 & 12.40 & 70.83 & 4.42 & 27.18 & $25.29 \pm 0.67$ & 35 & $27.80 \pm 0.82$ & 0.047 & 0.033 \\
\hline $\mathrm{O}_{7}$ & 6.52 & 12.25 & 71.26 & 4.77 & 23.19 & $25.22 \pm 0.73$ & 35 & $31.20 \pm 2.52$ & 0.013 & 0.016 \\
\hline
\end{tabular}

a $\mathrm{X}_{1}-\mathrm{PVP}, \mathrm{X}_{2}-$ starch $1500, \mathrm{X}_{3}$ - lactose, $\mathrm{X}_{4}$ - sodium starch glycolate

b Predicted values.

c Observed values.

${ }^{\mathrm{d}}$ Mean \pm SD. 
usual acceptance criteria provided by the US Pharmacopeia for drug products (15). In order to evaluate the content uniformity of tablets, the acceptance value (AV) was calculated based on the US Pharmacopeia; it was equal to 14.88. Since AV was lower than 15 (maximum allowed acceptance value) (15), adequate and homogenous distribution of the drug in tablets can be concluded.

Table VI includes the data on drug dissolved from the optimized formulation $\left(\mathrm{O}_{1}\right)$ tablets in $5\left(Q_{5}\right)$ and 15 min $\left(Q_{15}\right)$ after starting the dissolution test. It is apparent that in the first $5 \mathrm{~min}, 89.0 \pm 3.7 \%$ of the drug was dissolved in the medium which increased to $94.1 \pm 0.6 \%$ in $15 \mathrm{~min}$. According to the literature, the amount of drug dissolved from sublingual tablets must exceed $80 \%$ in 15 min (20). Thus, the prepared optimized tablet met the above mentioned dissolution requirement.

\section{Stability studies}

Physical properties of the optimized formulation $\left(\mathrm{O}_{1}\right)$ after keeping it in accelerated stability conditions $\left(45^{\circ} \mathrm{C}\right.$ and $\left.75 \% \mathrm{RH}\right)$ are illustrated in Table VI. Hardness of tablets was in the range of $24.93-27.32 \mathrm{~N}$, which was considered acceptable for sublingual tablet formulations. After being exposed to the stability testing conditions for three months, although disintegration time and friability of sublingual tablets increased from 32.57 to $45 \mathrm{~s}$ and 0.002 to $0.012 \%$ respectively, the tablets were still within the constraints defined for these variables (Table II). Drug content of tablets ranged from 97.5 to $96.2 \%$ at the end of stability studies.

The results of dissolution studies for tablets after stability experiments are represented in Table VI. It is shown that the data were very close to the freshly prepared tablet and more than $80 \%$ of physostigmine salicylate got dissolved from all tablets in the first $5 \mathrm{~min}$ of the test $\left(\mathrm{Q}_{5}\right)$. As mentioned above, the disintegration time of tablets exposed to the stability testing conditions was increased compared to fresh tablets. Slight decrease of the drug dissolved from the tablets in the first 5 min could be attributed to

Table VI. Physicochemical characteristics of the optimized formulation $\left(\mathrm{O}_{1}\right)$ after accelerated stability studies $\left(45{ }^{\circ} \mathrm{C}, 75 \% \mathrm{RH}\right)$

\begin{tabular}{lcccc}
\hline \multirow{2}{*}{ Dependent variable } & 0 & 1 & 2 & 3 \\
\cline { 2 - 5 } & $24.93 \pm 1.14$ & $24.93 \pm 1.41$ & $27.25 \pm 1.38$ & $27.32 \pm 1.39$ \\
\hline Hardness (N) $(n=10)^{\mathrm{a}}$ & 0.002 & 0.008 & 0.010 & 0.012 \\
Disintegration time (s) $(n=6)^{\mathrm{a}}$ & $32.57 \pm 3.25$ & $40.00 \pm 0.75$ & $45.00 \pm 2.1$ & $45 \pm 1.75$ \\
Friability (\%) $(n=20)$ & $97.50 \pm 1.50$ & $96.90 \pm 2.70$ & $96.60 \pm 1.75$ & $96.20 \pm 1.25$ \\
Drug content (\%) $(n=3)^{\mathrm{a}}$ & $89.00 \pm 3.70$ & $87.90 \pm 2.79$ & $87.80 \pm 3.10$ & $85.00 \pm 2.80$ \\
$\mathrm{Q}_{5}{ }^{\mathrm{b}}(\%)(n=3)^{\mathrm{a}}$ & $94.05 \pm 0.63$ & $93.30 \pm 2.14$ & $93.50 \pm 1.98$ & $94.39 \pm 2.51$ \\
$\mathrm{Q}_{15}{ }^{\mathrm{c}}(\%)(n=3)^{\mathrm{a}}$ & & & &
\end{tabular}

a Mean \pm SD.

b Drug dissolved in 5 min.

c Drug dissolved in $15 \mathrm{~min}$. 
this finding. However, according to the statistical analysis (ANOVA), no significant difference was observed for the drug dissolved from tablets during the stability test. In conclusion, the optimized formulation $\mathrm{O}_{1}$ could be considered stable even after 3 months of being kept under accelerated stability conditions.

\section{CONCLUSIONS}

Sublingual tablet of physostigmine salicylate with PVP, starch 1500, lactose and sodium starch glycolate as variable components was prepared and optimized using D-optimal mixture experimental design. The quantitative effect of these factors on tablet hardness, friability and disintegration time could be predicted by a special cubic model. The observed values of the responses obtained from the optimized formulation were very close to the predicted values. The results have confirmed that the D-optimal design technique can be successfully employed for designing a sublingual tablet with desirable physical properties.

Acknowledgments. - Authors would like to thank Dr. R. Ghalandari and Dr. H. Ettehadi of the Shaheed Meisamy Research and Development Institute for their cooperation and financial support.

\section{REFERENCES}

1. Martindale, The Complete Drug Reference, 35 ${ }^{\text {th }}$ ed., Pharmaceutical Press, London 2007, p. 1723.

2. M. N. Madhat, Buccal and Sublingual Administration of Physostigmine, U.S. Pat. 6,264,974, 24 Jul 2001.

3. R. Whelpton and P. Hurst, Bioavailability of oral physostigmine, New Eng. J. Med. 313 (1985) 1293-1294.

4. D. Harris and J. R. Robinson, Drug delivery via the mucous membranes of the oral cavity, J. Pharm. Sci. 81 (1992) 1-10; DOI: 10.1002/jps.2600810102.

5. P. Mura, S. Furlanetto, M. Cirri, F. Maestrelli, A. M. Marras and S. Pinzauti, Optimization of glibenclamide tablet composition through the combined use of differential scanning calorimetry and D-optimal mixture experimental design, J. Pharm. Biomed. Anal. 37 (2005) 65-71.

6. R. C. Hwang and D. L. Kowalski, Design of experiments for formulation development, Pharm Tech Dec 1, 2005.

7. Introduction to Experimental Design, in Pharmaceutical Experimental Design and Interpretation, $2^{\text {nd }}$ ed., N. A. Armstrong (Ed.), Taylor \& Francis, London 2006, pp. 1-8.

8. X. Jin, Y. Zhang, L. Xiao and Z. Zhao, Optimization of extended zero-order release gliclazide tablets using D-optimal mixture design, J. Pharm. Soc. Japan 128 (2008) 1475-1483.

9. Y. El-Malah, S. Nazzal and N. M. Khanfar, D-optimal mixture design: optimization of ternary matrix blends for controlled zero-order drug release from oral dosage forms, Drug Dev. Ind. Pharm. 32 (2006) 1207-1218; DOI: 10.1080/03639040600685167.

10. S. S. Patel, S. Ray and R. S. Thakur, Formulation and evaluation of floating drug delivery system containing clarithromycin for Helicobacter pylori, Acta Pol. Pharm. 63 (2006) 53-61.

11. Y. Gonnissen, S. I. Gonçalves, J. P. Remon and C. Vervaet, Mixture design applied to optimize a directly compressible powder produced via cospray drying, Drug Dev. Ind. Pharm. 34 (2008) 248-257; DOI: 10.1080/03639040701542143. 
N. Bolourchian et al.: Development and optimization of a sublingual tablet formulation for physostigmine salicylate, Acta Pharm. 59 (2009) 301-312.

12. T. Nahata and T. R. Saini, D-optimal designing and optimization of long acting microsphere-based injectable formulation of aripiprazole, Drug Dev. Ind. Pharm. 34 (2008) 668-675; DOI: 10.1080/ 03639040701836545.

13. A. Bodea and S. E. Leucuta, Optimization of hydrophilic matrix tablets using a D-optimal design, Int. J. Pharm. 153 (1997) 247-255; DOI: 10.1016/S0378-5173(97)00117-8.

14. R. C. Rowe, P. J. Sheskey and P. J. Weller, Handbook of Pharmaceutical Excipients, $5^{\text {th }}$ ed., Pharmaceutical Press and American Pharmaceutical Association, London 2006.

15. United States Pharmacopeia 31, National Formulary 26, The United States Pharmacopeial Convention, Rockville 2008.

16. S. J. Ugarkovic, Sublingual Oral Dosage Form, U.S. Pat. 6,572,891, 3 Jun 2003.

17. G. Derringer and R. Suich, Simultaneous optimization of several response variables, J. Qual. Tech. 12 (1980) 214-219.

18. H. L. Fung, S. K. Yap and C. T. Rhodes, Development of a stable sublingual nitroglycerin tablet II: formulation and evaluation of tablets containing povidone, J. Pharm. Sci. 65 (1976) 558-560; DOI: $10.1002 / j p s .2600650419$.

19. C. P. Lim, S. S. Quek and K. K. Peh, Prediction of drug release profiles using an intelligent learning system: an experimental study in transdermal iontophoresis, J. Pharm. Biomed. Anal. 31 (2003) 159-168; DOI: 10.1016/S0731-7085(02)00573-3.

20. J. Klancke, Dissolution testing of orally disintegrating tablets, Diss. Tech. 10 (2003) 6-8.

\section{$S A \check{Z} E T A K$}

\section{Razvoj i optimizacija sublingvalnih tableta fizostigmin salicilata}

NOUSHIN BOLOURCHIAN, NAGHMEH HADIDI, SEYED MOHSEN FOROUTAN i BIJAN SHAFAGHI

Cilj rada bio je dizajnirati i optimirati sublingvalne tablete fizostigmin salicilata, lijeka učinkovitog u terapiji Alzheimerove bolesti i intoksikacije nervnim plinovitim otrovima, koristeći metodologiju D-optimalnog eksperimentalnog dizajniranja. U formulacijama su kao nezavisne varijable korišteni polivinil pirolidon, laktoza, škrob 1500 i natrijev škrobni glikolat. Tablete su pripravljene metodom izravne kompresije. Njihova fizikalna svojstva (tvrdoća, vrijeme dezintegracije i lomljivost) evaluirana su kao zavisna varijabla u Doptimalnom dizajniranju. Rezultati su najbolje slijedili specijalni kubični model, pa je taj model upotrijebljen za ispitivanje rezultata. Nacrtane su krivulje ovisnosti za proučavanje svojstava tableta. Na temelju njih izrađen je i optimirani prekrivni prikaz prema rezultatima i postavljenim ciljevima za odgovor na lijek. Poslije provjere najboljih kontrolnih formulacija, izabrana je jedna optimirana formulacija temeljem svojih poželjnih fizičkih značajki te uočenih i predviđenih vrijednosti. Ispitivanje lijeka, jednolikosti sadržaja, oslobađanja lijeka i pokusi ubrzanog starenja provedeni su na optimiranoj formulaciji. Dobiveni rezultati odgovaraju zahtjevima za tablete za sublingvalnu primjenu.

Ključne riječi: D-optimalno dizajniranje sastava, fizostigmin salicilat, sublingvalne tablete, stabilnost School of Pharmacy, Shahid Beheshti University (M.C.), Tehran, Iran

Pharmaceutical Sciences Research Center, Shahid Beheshti University (M.C.), Tehran, Iran 